\title{
Antibacterial properties of imipenem with special reference to the activity against methicillin-resistant staphylococci, cefotaxime-resistant Enterobacteriaceae and Pseudomonas aeruginosa
}

\author{
U. Vurma-Rapp, F. H. Kayser and L. Barberis-Maino \\ Institute of Medical Microbiology, University of Zürich, CH-8028 Zürich P.O. Box, \\ Switzerland
}

\begin{abstract}
Imipenem was examined with standardized agar dilution procedures against a wide range of bacteria. Geometric mean MICs against the genera Escherichia, Klebsiella, Enterobacter, Citrobacter and Serratia were $0.1-0.4 \mathrm{mg} / 1$, and Proteus and Providencia spp. were inhibited by $0 \cdot 25-4 \mathrm{mg} / \mathrm{l}$. Acinetobacter calcoaceticus var. anitratum strains were inhibited by concentrations ranging from $0 \cdot 12-0.5 \mathrm{mg} / 1$. Methicillin-susceptible staphylococci were highly susceptible to the drug (MICs: $\leqslant 0.03 \mathrm{mg} / \mathrm{l})$ and enterococci were inhibited by $0.25-16 \mathrm{mg} / \mathrm{l}$. Most of the multiresistant $\mathbf{J K}$ corynebacteria were resistant to imipenem. Imipenem was more active than any other $\beta$-lactam against methicillin-resistant staphylococci; this was also demonstrated in a population analysis. Imipenem-resistant minorities in populations, however, were also observed. Cefotaxime-resistant and -intermediate Enterobacter and Citrobacter strains were inhibited by concentrations of $0.5 \mathrm{mg} / 1 \mathrm{or}$ less. No third-generation cephalosporin nor any other $\beta$-lactam showed similarly high activity against these groups of organisms. Among 20 ceftazidime-resistant and 20 ceftazidime-susceptible isolates of Pseudomonas aeruginosa, no strain was resistant and only five ceftazidime-resistant strains were intermediately susceptible (MIC, $8 \mathrm{mg} / 1$ ) to imipenem.
\end{abstract}

\section{Introduction}

The aim of this work was to study the in-vitro activity of imipenem in comparison with other broad-spectrum $\beta$-lactam antibiotics against a wide range of bacteria.

\section{Materials and methods}

\section{Organisms}

The bacterial strains used were recently isolated from clinical specimens and identified according to standard procedures.

\section{Antibiotics}

Imipenem (Merck, Sharp \& Dohme), ceftazidime (Glaxo), aztreonam (Squibb), cefotaxime (Hoechst), cefpirome (HR810) (Hoechst-Roussel), ceftriaxone (Hoffman La Roche), cefoperazone (Pfizer) and latamoxef (Lilly) were kindly supplied by the manufacturers. 
Table I. In-vitro activity of imipenem and seven $\beta$-lactam antibiotics against Enterobacteriaceae

\begin{tabular}{|c|c|c|c|c|c|}
\hline \multirow[b]{2}{*}{$\begin{array}{l}\text { Organisms } \\
\text { (no. of strains) }\end{array}$} & \multirow[b]{2}{*}{ Drug } & \multicolumn{4}{|c|}{$\mathrm{MIC}(\mathrm{mg} / \mathrm{l})$} \\
\hline & & $50 \%^{a}$ & $90 \% \%^{a}$ & Range & $\begin{array}{l}\text { Geometric } \\
\text { mean }\end{array}$ \\
\hline Esch. coli (12) & $\begin{array}{l}\text { imipenem } \\
\text { ceftazidime } \\
\text { aztreonam } \\
\text { cefpirome } \\
\text { cefotaxime } \\
\text { ceftriaxone } \\
\text { cefoperazone } \\
\text { latamoxef }\end{array}$ & $\begin{array}{l}0 \cdot 12 \\
8 \\
4 \\
0 \cdot 06 \\
2 \\
1 \\
2 \\
0 \cdot 5\end{array}$ & $\begin{array}{l}0 \cdot 25 \\
16 \\
8 \\
0 \cdot 25 \\
4 \\
1 \\
16 \\
1\end{array}$ & $\begin{array}{c}\leqslant 0 \cdot 03-0 \cdot 5 \\
0 \cdot 12-16 \\
0 \cdot 06-8 \\
\leqslant 0 \cdot 03-1 \\
0 \cdot 06-4 \\
\leqslant 0 \cdot 03-1 \\
0 \cdot 5-64 \\
0 \cdot 06-1\end{array}$ & $\begin{array}{l}0 \cdot 11 \\
2 \cdot 1 \\
1 \cdot 1 \\
0 \cdot 09 \\
0 \cdot 89 \\
0 \cdot 40 \\
2 \cdot 0 \\
0 \cdot 33\end{array}$ \\
\hline Klebsiella spp. (27) & $\begin{array}{l}\text { imipenem } \\
\text { ceftazidime } \\
\text { aztreonam } \\
\text { cefpirome } \\
\text { cefotaxime } \\
\text { ceftriaxone } \\
\text { cefoperazone } \\
\text { latamoxef }\end{array}$ & $\begin{array}{c}0 \cdot 12 \\
0.25 \\
8 \\
0.5 \\
0 \cdot 5 \\
2 \\
128 \\
0 \cdot 12\end{array}$ & $\begin{array}{c}0 \cdot 25 \\
0 \cdot 5 \\
32 \\
2 \\
2 \\
64 \\
256 \\
1\end{array}$ & $\begin{aligned} & 0 \cdot 06-1 \\
& 0 \cdot 06-16 \\
\leqslant & 0 \cdot 03-64 \\
\leqslant & 0 \cdot 03-4 \\
& 0 \cdot 06-16 \\
\leqslant & 0 \cdot 03-128 \\
& 0 \cdot 25-512 \\
\leqslant & 0 \cdot 03-16\end{aligned}$ & $\begin{array}{l}0 \cdot 15 \\
0 \cdot 23 \\
1 \cdot 8 \\
0 \cdot 36 \\
0 \cdot 38 \\
1 \cdot 1 \\
38 \cdot 3 \\
0 \cdot 14\end{array}$ \\
\hline $\begin{array}{l}\text { Enterobacter spp. cefotaxime } \\
\text { susceptible (11) }\end{array}$ & $\begin{array}{l}\text { imipenem } \\
\text { ceftazidime } \\
\text { aztreonam } \\
\text { cefpirome } \\
\text { cefotaxime } \\
\text { ceftriaxone } \\
\text { cefoperazone } \\
\text { latamoxef }\end{array}$ & $\begin{array}{l}0 \cdot 25 \\
1 \\
0 \cdot 25 \\
0 \cdot 25 \\
2 \\
4 \\
8 \\
0 \cdot 5\end{array}$ & $\begin{array}{c}1 \\
16 \\
4 \\
0 \cdot 5 \\
8 \\
8 \\
8 \\
1\end{array}$ & $\begin{aligned} & 0.06-1 \\
& 0.25-16 \\
& \leqslant 0.03-16 \\
& \leqslant 0 \cdot 03-0.5 \\
& 0.06-8 \\
& 0.06-16 \\
& 0.06-16 \\
& 0 \cdot 06-1\end{aligned}$ & $\begin{array}{l}0 \cdot 30 \\
1 \cdot 6 \\
0 \cdot 47 \\
0 \cdot 22 \\
1 \cdot 4 \\
1 \cdot 5 \\
3 \cdot 3 \\
0 \cdot 34\end{array}$ \\
\hline $\begin{array}{l}\text { Enterobacter spp. cefotaxime } \\
\text { intermediate/resistant ( } 21)\end{array}$ & $\begin{array}{l}\text { imipenem } \\
\text { ceftazidime } \\
\text { aztreonam } \\
\text { cefpirome } \\
\text { cefotaxime } \\
\text { ceftriaxone } \\
\text { cefoperazone } \\
\text { latamoxef }\end{array}$ & $\begin{array}{c}0 \cdot 25 \\
128 \\
32 \\
4 \\
128 \\
128 \\
64 \\
8\end{array}$ & $\begin{array}{c}0 \cdot 5 \\
256 \\
64 \\
8 \\
256 \\
512 \\
256 \\
16\end{array}$ & $\begin{array}{c}\leqslant 0 \cdot 03-0 \cdot 5 \\
16->512 \\
4-128 \\
0 \cdot 5-128 \\
16->512 \\
16->512 \\
16->512 \\
0.5-128\end{array}$ & $\begin{array}{c}0 \cdot 20 \\
101 \cdot 6 \\
32 \cdot 0 \\
2 \cdot 6 \\
115 \cdot 9 \\
119 \cdot 8 \\
89 \cdot 0 \\
6 \cdot 1\end{array}$ \\
\hline $\begin{array}{l}\text { C. freundii cefotaxime } \\
\text { susceptible (13) }\end{array}$ & $\begin{array}{l}\text { imipenem } \\
\text { ceftazidime } \\
\text { aztreonam } \\
\text { cefpirome } \\
\text { cefotaxime } \\
\text { ceftriaxone } \\
\text { cefoperazone } \\
\text { latamoxef }\end{array}$ & $\begin{array}{l}0 \cdot 25 \\
0 \cdot 25 \\
0 \cdot 25 \\
0 \cdot 12 \\
1 \\
0 \cdot 5 \\
8 \\
0 \cdot 06\end{array}$ & $\begin{array}{l}0 \cdot 25 \\
4 \\
2 \\
0 \cdot 5 \\
4 \\
8 \\
16 \\
0 \cdot 5\end{array}$ & $\begin{aligned} & 0 \cdot 12-1 \\
& 0 \cdot 12-4 \\
& \leqslant 0 \cdot 03-2 \\
& \leqslant 0 \cdot 03-1 \\
& 0 \cdot 06-4 \\
& \leqslant 0 \cdot 03-8 \\
& 0 \cdot 12-64 \\
& 0.06-8\end{aligned}$ & $\begin{array}{l}0 \cdot 24 \\
0 \cdot 62 \\
0 \cdot 29 \\
0 \cdot 14 \\
0 \cdot 85 \\
0 \cdot 56 \\
5 \cdot 5 \\
0 \cdot 16\end{array}$ \\
\hline $\begin{array}{l}\text { C. freundii cefotaxime } \\
\text { intermediate/resistant (17) }\end{array}$ & $\begin{array}{l}\text { imipenem } \\
\text { ceftazidime } \\
\text { aztreonam } \\
\text { cefpirome } \\
\text { cefotaxime } \\
\text { ceftriaxone } \\
\text { cefoperazone } \\
\text { latamoxef }\end{array}$ & $\begin{array}{c}0 \cdot 12 \\
128 \\
32 \\
2 \\
64 \\
64 \\
64 \\
2\end{array}$ & $\begin{array}{c}0 \cdot 25 \\
512 \\
128 \\
4 \\
128 \\
256 \\
256 \\
8\end{array}$ & $\begin{array}{c}0 \cdot 12-0 \cdot 25 \\
32-512 \\
8-256 \\
0 \cdot 25-4 \\
16-128 \\
16-256 \\
32-256 \\
1-32\end{array}$ & $\begin{array}{c}0 \cdot 15 \\
156 \cdot 9 \\
39 \cdot 2 \\
1 \cdot 6 \\
50 \cdot 1 \\
81 \cdot 7 \\
81 \cdot 7 \\
3 \cdot 7\end{array}$ \\
\hline
\end{tabular}


Table I-contd.

\begin{tabular}{|c|c|c|c|c|c|}
\hline \multirow[b]{2}{*}{$\begin{array}{l}\text { Organisms } \\
\text { (no. of strains) }\end{array}$} & \multirow[b]{2}{*}{ Drug } & \multicolumn{4}{|c|}{$\mathrm{MIC}(\mathrm{mg} / \mathrm{l})$} \\
\hline & & $50 \%^{a}$ & $90 \%^{a}$ & Range & $\begin{array}{c}\text { Geometric } \\
\text { mean }\end{array}$ \\
\hline \multirow[t]{8}{*}{ Ser. marcescens (25) } & imipenem & $0 \cdot 5$ & 0.5 & $0 \cdot 12-1$ & 0.41 \\
\hline & ceftazidime & 0.5 & 2 & $0.06-16$ & 0.44 \\
\hline & aztreonam & 0.5 & 8 & $0.06-8$ & 0.74 \\
\hline & cefpirome & $0 \cdot 5$ & 1 & $\leqslant 0.03-4$ & $0 \cdot 34$ \\
\hline & cefotaxime & 8 & 32 & $0 \cdot 12-32$ & $3 \cdot 1$ \\
\hline & ceftriaxone & 2 & 16 & $0 \cdot 06-32$ & $1 \cdot 7$ \\
\hline & cefoperazone & 64 & 128 & 8-128 & $43 \cdot 4$ \\
\hline & latamoxef & $0 \cdot 25$ & 8 & $0 \cdot 12-16$ & $0 \cdot 76$ \\
\hline \multirow{8}{*}{$\begin{array}{l}\text { Proteus and Providencia } \\
\text { spp. }{ }^{b}(19)\end{array}$} & imipenem & 1 & 2 & $0 \cdot 25-4$ & $0 \cdot 75$ \\
\hline & ceftazidime & $0 \cdot 06$ & 0.5 & $\leqslant 0 \cdot 03-1$ & 0.05 \\
\hline & aztreonam & $\leqslant 0.03$ & 0.03 & $\leqslant 0.03-0.06$ & $\leqslant 0 \cdot 03$ \\
\hline & cefpirome & $0 \cdot 5$ & 4 & $0 \cdot 12-4$ & 0.77 \\
\hline & cefotaxime & $\leqslant 0.03$ & 0.06 & $\leqslant 0 \cdot 03-0 \cdot 25$ & $\leqslant 0.03$ \\
\hline & ceftriaxone & $\leqslant 0.03$ & 0.03 & $\leqslant 0.03-0.06$ & $\leqslant 0.03$ \\
\hline & cefoperazone & $\leqslant 0.03$ & 0.03 & $\leqslant 0.03-0.06$ & $\leqslant 0.03$ \\
\hline & latamoxef & $0 \cdot 25$ & 0.5 & $\leqslant 0.03-0.5$ & $0 \cdot 17$ \\
\hline
\end{tabular}

${ }^{a} \mathrm{MIC}_{50}$ and $\mathrm{MIC}_{90}$ are the concentrations of antibiotics required to inhibit $50 \%$ and $90 \%$ of the examined strains, respectively.

${ }^{b}$ Prot. mirabilis (6), Prot. vulgaris (6), Prov. rettgeri (4), Prov. stuartii (3).

\section{Methods}

Minimal inhibitory concentrations (MICs) were determined according to the NCCLS agar-dilution procedure (National Committee for Clinical Laboratory Standards (NCCLS) (1985)). Mueller-Hinton medium with 3\% agar content was used to prevent swarming of Providencia and Proteus spp. Gonococci (GC) agar base supplemented with $5 \%$ defibrinated sheep blood was used for JK corynebacteria.

A population of methicillin-resistant staphylococci was analysed by disaggregation of overnight broth cultures (brief ultrasonication at $20 \mathrm{kHz}$ ) and surface inoculation on to drug-containing Mueller-Hinton agar plates with $0.1 \mathrm{ml}$ of appropriate dilutions of the processed broth. Incubation was at $37^{\circ} \mathrm{C}$ for $48 \mathrm{~h}$. Colony counts served to calculate the number of resistant cells in a population of $10^{8} \mathrm{cfu}$.

\section{Results}

The MICs for the Gram-negative and Gram-positive organisms used to define the spectrum of imipenem are presented in Tables I to III. Imipenem was highly active against the Enterobacteriaceae; exceeding the activity of most of the other $\beta$-lactam antibiotics tested (Table I). The drug showed less activity against Proteus and Providencia spp., but MICs were still below the susceptibility threshold of $\leqslant 4 \mathrm{mg} /$. Imipenem was equally active against Enterobacter and Citrobacter strains resistant or susceptible to cefotaxime. Most of the cefotaxime-resistant strains were also resistant to ceftazidime, aztreonam, ceftriaxone and cefoperazone. Cefpirome and latamoxef 
Table II. In-vitro activity of imipenem and seven $\beta$-lactam antibiotics against $A$. anitratus and Ps. aeruginosa

\begin{tabular}{llrrrr}
\hline & & \multicolumn{3}{c}{ MIC (mg/l) } \\
\cline { 3 - 6 } $\begin{array}{l}\text { Organisms } \\
\text { (no. of strains) }\end{array}$ & \multicolumn{1}{c}{ Drug } & $50 \%$ & $90 \%$ & Range & $\begin{array}{c}\text { Geometric } \\
\text { mean }\end{array}$ \\
\hline A. calcoaceticus var. & imipenem & $0 \cdot 25$ & $0 \cdot 5$ & $0 \cdot 12-0 \cdot 5$ & $0 \cdot 21$ \\
anitratum (11) & ceftazidime & 8 & 16 & $4-16$ & $8 \cdot 5$ \\
& aztreonam & 32 & 64 & $16-64$ & $36 \cdot 3$ \\
& cefpirome & 32 & 64 & $1-64$ & $20 \cdot 6$ \\
& cefotaxime & 16 & 32 & $4-32$ & $17 \cdot 0$ \\
& ceftriaxone & 16 & 32 & $4-32$ & $14 \cdot 1$ \\
& cefoperazone & 128 & 256 & $128-256$ & $164 \cdot 7$ \\
Ps. aeruginosa ceftazidime & latamoxef & 16 & 16 & $2-32$ & $13 \cdot 2$ \\
susceptible (20) & imipenem & 1 & 2 & $0 \cdot 5-4$ & $1 \cdot 1$ \\
& ceftazidime & 2 & 4 & $1-8$ & $2 \cdot 1$ \\
& aztreonam & 4 & 16 & $2-32$ & $5 \cdot 9$ \\
& cefpirome & 8 & 16 & $2-64$ & $7 \cdot 7$ \\
& cefotaxime & 16 & 64 & $8-256$ & $26 \cdot 0$ \\
& ceftriaxone & 32 & 128 & $8-256$ & $29 \cdot 9$ \\
& cefoperazone & 8 & 64 & $4-128$ & $11 \cdot 3$ \\
Ps. aeruginosa ceftazidime & latamoxef & 16 & 32 & $8-128$ & $16 \cdot 0$ \\
intermediate/resistant (20) & imipenem & 4 & 8 & $0 \cdot 5-8$ & $2 \cdot 8$ \\
& ceftazidime & 64 & 64 & $16-256$ & $46 \cdot 9$ \\
& aztreonam & 64 & 128 & $8-128$ & $50 \cdot 2$ \\
& cefpirome & 256 & 512 & $2-512$ & $119 \cdot 4$ \\
& cefotaxime & 512 & $<512$ & $32->512$ & 512 \\
& ceftriaxone & $>512$ & $>512$ & $32->512$ & $675 \cdot 6$ \\
& cefoperazone & 256 & 512 & $8->512$ & $230 \cdot 7$ \\
& latamoxef & 128 & 256 & $16-512$ & $152 \cdot 2$ \\
\hline
\end{tabular}

exerted good activity against these problem strains, although the geometric means of their MICs were 10-20 times higher than against cefotaxime-susceptible Enterobacter and Citrobacter spp.

Imipenem was the most active amongst the agents tested against Acinetobacter calcoaceticus var. anitratum and Pseudomonas aeruginosa, whether susceptible or resistant to ceftazidime (Table II). MICs of imipenem against ceftazidime-resistant Ps. aeruginosa were only slightly higher than against susceptible strains. This finding was in sharp contrast to the results obtained with the other $\beta$-lactams. The latter all showed highly elevated MICs against the ceftazidime-resistant strains. Cross-resistance was not observed between imipenem and the other drugs examined. Imipenem was highly active against methicillin-susceptible staphylococci (Table III). Compared with the activity against other Gram-positive bacteria (Tischhauser \& Kayser, 1983), the drug's activity against enterococci was relatively low. However, $50 \%$ of the enterococci were inhibited by $1 \mathrm{mg} / 1$ and $90 \%$ by $8 \mathrm{mg} / 1$ of the drug, respectively. These values were much lower than those of the other $\beta$-lactams examined. Antistaphylococcal activity of imipenem was generally superior to that of the other $\beta$-lactams tested. Methicillinresistant staphylococci were inhibited by higher imipenem concentrations than susceptible isolates but only $5 \%$ of the strains had MICs above the susceptibility 
Table III. In-vitro activity of imipenem and six $\beta$-lactam antibiotics against Gram-positive organisms

\begin{tabular}{|c|c|c|c|c|c|}
\hline \multirow[b]{2}{*}{$\begin{array}{l}\text { Organisms } \\
\text { (no. of strains) }\end{array}$} & \multirow[b]{2}{*}{ Drug } & \multicolumn{4}{|c|}{ MIC (mg/l) } \\
\hline & & $50 \%$ & $90 \%$ & Range & $\begin{array}{c}\text { Geometric } \\
\text { mean }\end{array}$ \\
\hline \multirow{7}{*}{$\begin{array}{l}\text { Staph. aureus methicillin } \\
\text { susceptible (19) }\end{array}$} & imipenem & $\leqslant 0.03$ & $\leqslant 0.03$ & $\leqslant 0.03$ & $\leqslant 0.03$ \\
\hline & ceftazidime & 8 & 16 & $4-16$ & 8.9 \\
\hline & cefpirome & 1 & 1 & $0 \cdot 12-1$ & 0.58 \\
\hline & cefotaxime & 2 & 4 & $0.5-4$ & $1 \cdot 7$ \\
\hline & ceftriaxone & 4 & 8 & 1-8 & $3 \cdot 0$ \\
\hline & cefoperazone & 2 & 4 & $1-4$ & 1.9 \\
\hline & latamoxef & 16 & 16 & $8-16$ & $9 \cdot 3$ \\
\hline \multirow{7}{*}{$\begin{array}{l}\text { Staph. aureus methicillin } \\
\text { resistant (19) }\end{array}$} & imipenem & $\leqslant 0.03$ & $0 \cdot 12$ & $\leqslant 0 \cdot 03-64$ & 0.07 \\
\hline & ceftazidime & 32 & 128 & 4-512 & $32 \cdot 0$ \\
\hline & cefpirome & 2 & 32 & $0 \cdot 5-64$ & $2 \cdot 5$ \\
\hline & cefotaxime & 16 & 128 & $1->512$ & $12 \cdot 4$ \\
\hline & ceftriaxone & 16 & 256 & $2->512$ & 17.9 \\
\hline & cefoperazone & 16 & 32 & $1->512$ & $15 \cdot 4$ \\
\hline & latamoxef & 32 & 128 & $8->512$ & $33 \cdot 2$ \\
\hline Coagulase-negative & imipenem & $\leqslant 0.03$ & $\leqslant 0.03$ & $\leqslant 0.03$ & $\leqslant 0.03$ \\
\hline staphylococcus methicillin & ceftazidime & 8 & 16 & $4-16$ & $6 \cdot 7$ \\
\hline \multirow[t]{5}{*}{ susceptible (16) } & cefpirome & 0.25 & 0.5 & $0 \cdot 12-2$ & $0 \cdot 25$ \\
\hline & cefotaxime & 1 & 4 & $0 \cdot 5-8$ & $1 \cdot 6$ \\
\hline & ceftriaxone & 2 & 4 & $0.5-8$ & $1 \cdot 5$ \\
\hline & cefoperazone & 2 & 4 & $0.5-4$ & 1.5 \\
\hline & latamoxef & 16 & 32 & $8-32$ & $18 \cdot 2$ \\
\hline Coagulase-negative & imipenem & 0.06 & $0 \cdot 5$ & $\leqslant 0.03-16$ & 0.09 \\
\hline staphylococcus methicillin & ceftazidime & 8 & 32 & $0 \cdot 5-32$ & 8.9 \\
\hline \multirow[t]{5}{*}{ resistant (20) } & cefpirome & $0 \cdot 5$ & 4 & $0.06-16$ & 0.71 \\
\hline & cefotaxime & 2 & 8 & $0 \cdot 06-16$ & $2 \cdot 3$ \\
\hline & ceftriaxone & 4 & 32 & $0 \cdot 12-32$ & $4 \cdot 4$ \\
\hline & cefoperazone & 2 & 4 & $0 \cdot 25-8$ & $2 \cdot 1$ \\
\hline & latamoxef & 32 & 64 & $8-128$ & $34 \cdot 3$ \\
\hline \multirow[t]{7}{*}{ Enterococci (20) } & imipenem & 1 & 8 & $0 \cdot 25-16$ & 1.9 \\
\hline & ceftazidime & $>512$ & $>512$ & $128->512$ & $749 \cdot 6$ \\
\hline & cefpirome & 16 & 512 & $1->512$ & $34 \cdot 3$ \\
\hline & cefotaxime & 256 & 512 & $32->512$ & $294 \cdot 1$ \\
\hline & ceftriaxone & 128 & 512 & $4->512$ & $123 \cdot 6$ \\
\hline & cefoperazone & 64 & 512 & $8-512$ & $64 \cdot 0$ \\
\hline & latamoxef & $>512$ & $>512$ & $128->512$ & $861 \cdot 1$ \\
\hline \multirow{7}{*}{$\begin{array}{l}\text { Multiresistant JK } \\
\text { corynebacteria (14) }\end{array}$} & imipenem & 256 & 512 & $0.5 \rightarrow>512$ & 115.9 \\
\hline & ceftazidime & $>512$ & $>512$ & $128->512$ & $655 \cdot 8$ \\
\hline & cefpirome & 512 & $>512$ & $4->512$ & $141 \cdot 3$ \\
\hline & cefotaxime & $>512$ & $>512$ & $8->512$ & $269 \cdot 0$ \\
\hline & ceftriaxone & $>512$ & $>512$ & $8->512$ & $243 \cdot 6$ \\
\hline & cefoperazone & $>512$ & $>512$ & $16->512$ & $231 \cdot 9$ \\
\hline & latamoxef & $>512$ & $>512$ & $256->512$ & $760 \cdot 8$ \\
\hline
\end{tabular}

breakpoint of $4 \mathrm{mg} / \mathrm{l}$. Figure 1 shows the population analysis of the pencillinasenegative Staphylococcus aureus strain FK 362 with respect to imipenem, penicillin G and methicillin. Although heterogeneity was also found with imipenem, the population was more susceptible to imipenem than to penicillin $G$ and to methicillin. 


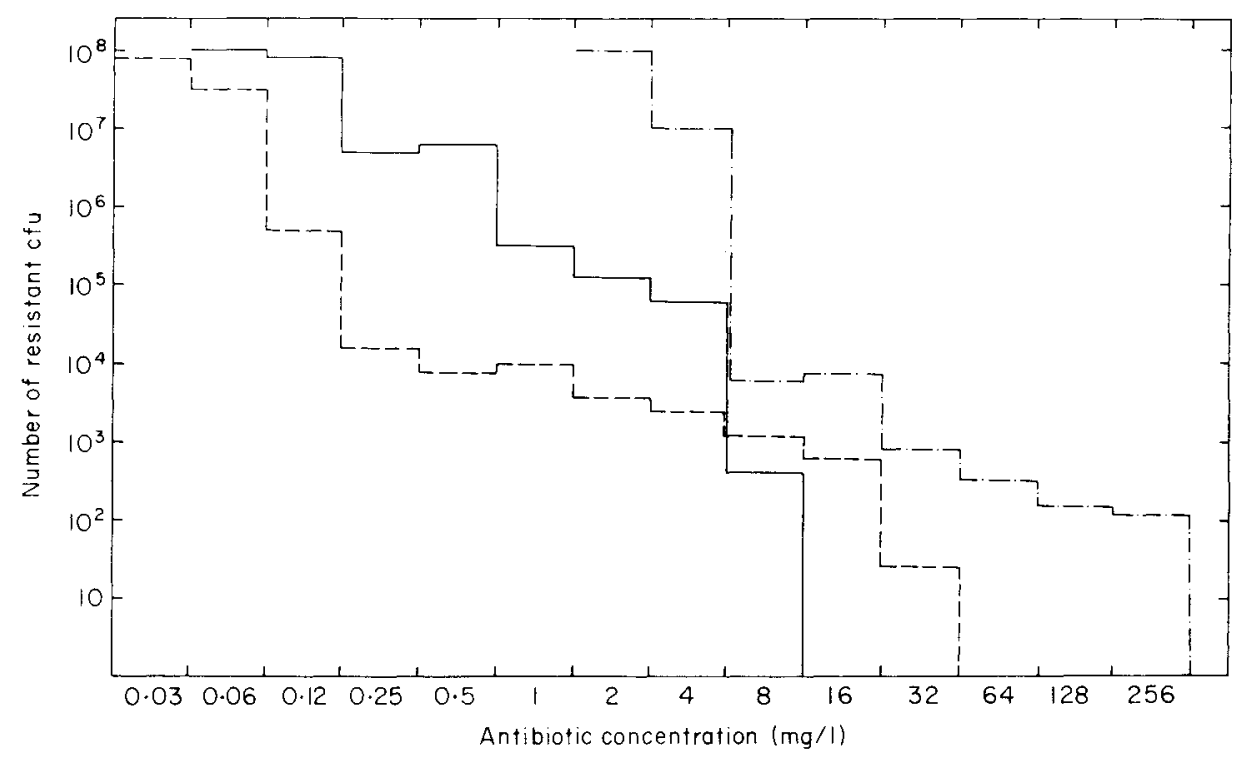

Figure 1. Number of viable units resistant to each concentration of antimicrobial agent remaining after plating an inoculum of $10^{8} \mathrm{cfu}$ of methicillin-resistant, $\beta$-lactamase-negative Staph. aureus strain FK 362 and incubating at $37^{\circ} \mathrm{C}$ for $48 \mathrm{~h}$ (- - - imipenem; —— penicillin $\mathrm{G}$; —. - - methicillin).

\section{Discussion}

An outstanding property of imipenem is its activity against strains of Enterobacteriaceae resistant to third-generation cephalosporins. This property may be due to the stability of imipenem to the chromosomal cephalosporinase responsible for resistance in these organisms (Livermore, Williams \& Williams, 1981; Seeberg, Tolxdorff-Neutzling \& Wiedemann, 1983) as well as its high penetrability through the outer membrane of Gram-negative bacteria due to its zwitterionic character and compact molecular structure (Yoshimura \& Nikaido, 1985). Stability to $\beta$-lactamases and good penetrability of the cell wall also could explain the activity of imipenem against ceftazidime-resistant $P$ s. aeruginosa.

Another outstanding feature of imipenem is its activity against Gram-positive cocci including the enterococci. The majority of the methicillin-resistant staphylococci were susceptible to imipenem in standard agar dilution tests, but with an inoculum of $10^{4}$ cells per spot and incubation for $20 \mathrm{~h}$ at $35^{\circ} \mathrm{C}$, these tests were unfavourable for the expression of intrinsic resistance to $\beta$-lactam antibiotics in staphylococci. The majority of cells in a population of methicillin-resistant Staph. aureus will be susceptible to imipenem, but minorities of a few more or less resistant cells may occur. Despite this situation, imipenem seems to be an effective agent in the treatment of infections caused by methicillin-resistant staphylococci (Fan et al., 1986).

Thus, imipenem presents an impressive potential in the therapy of bacterial infections.

\section{References}

Fan, W., Del Busto, R., Love, M., et al. (1986). Imipenem-cilastatin in the treatment of methicillin-sensitive and methicillin-resistant Staphylococcus aureus infections. Antimicrobial Agents and Chemotherapy 29, 26-9. 
Livermore, D. M., Williams, R. J. \& Williams, J.D. (1981). In-vitro activity of MK $0787(\mathrm{~N}$ formimidoylthienamycin) against Pseudomonas aeruginosa and other Gram-negative organisms and its stability to their $\beta$-lactamases. Journal of Antimicrobial Chemotherapy 8, $355-62$.

National Committee for Clinical Laboratory Standards (1985). Methods for dilution antimicrobial susceptibility tests for bacteria that grow aerobically; Approved Standard NCCLS publication M7-A. NCCLS, Villanova, $\mathrm{Pa}$.

Seeberg, A. H., Tolxdorff-Neutzling, R. M. \& Wiedemann, B. (1983). Chromosomal betalactamases of Enterobacter cloacae are responsible for resistance to third-generation cephalosporins. Antimicrobial Agents and Chemotherapy 23, 918-25.

Tischhauser, G. \& Kayser, F. H. (1983). The in vitro activity of $N$-formimidoyl thienamycin compared with other broad-spectrum cephalosporins and with clindamycin and metronidazole. Infection 11, 219-26.

Yoshimura, F. \& Nikaido, H. (1985). Diffusion of beta-lactam antibiotics through the porin channels of Escherichia coli K12. Antimicrobial Agents and Chemotherapy 27, 84-92. 